\title{
Rhymes, English and Hindu.
}

\section{N. Venkataswami}

To cite this article: M. N. Venkataswami (1901) Rhymes, English and Hindu., Folklore, 12:3, 330-335, DOI: 10.1080/0015587X.1901.9719642

To link to this article: http://dx.doi.org/10.1080/0015587X.1901.9719642

$$
\text { 曲 Published online: } 06 \text { Feb } 2012 .
$$

5 Submit your article to this journal $₫$

Џll Article views: 1

Q View related articles ¿ 
slaughter-house in Cairo. You will find there a very dirty dog in front of the house sitting on its hind legs. Give it this paper, and it will procure you the money." Although he disbelieved all this, the man took the paper, and when he reached Cairo went to the slaughter-house, where he found several clean good dogs, and finally a dirty one sitting on its hind legs. He gave it the paper. The dog read it, and said, "I will give you the money to-morrow. Return here at this time." The next day, when the man revisited the dog, he was told, "Come again to-norrow for the rest. I give you now half the money you require." On the morrow the dog said, "To-day I can complete three-quarters of the full amount. You shall receive the remainder to-morrow." On the following day the last instalment was paid. "Tell me," inquired the man of the dog, "who are you, who was he who gave me the paper, and how did you procure the money?" The dog replied, "The man whom you met is my king, and I am his slave. It was my king that wished to marry, but he had no corn. On the first day after you came here I could not find sufficient money for you. When a thief stole money, I also stole. Where he stole one guinea, ${ }^{1}$ I stole six. Thus I obtained for you the money." (Nile Valley, between Assiut and Luxor.)

C. S. Myers.

\title{
Rhymes, English and Hindu.
}

I. I. From Mr. Hills, a very old labourer, of Compton, near Newbury, June, igoo.2.

\author{
Churn, butter, churn ! \\ Come, butter, come ! \\ Peter stands at our gate, \\ Waiting for a butter-cake. \\ Churn, butter, churn! \\ Come, butter, come!
}

\footnotetext{
"The word "guinea" has become universally Arabicized in Egypt. It means an Egyptian pound, i.e., 100 piastres $=\mathscr{f} I$ os. $6 d$. It is the only common Egyptian word for such a coin, which is, as a fact, very rare, English gold being used (with the additional pence), as the equivalent of it.

2 Ellis's Brand, iii., 313. It is interesting to find a charm in use 350 years ago still extant, and in a more complete form than that originally recorded.
} 
2. From the same.

There was an old woman lived under a bill,

And three thieves came to rob her,

She cried out,

And made a great rout,

For the thieves had a mind to stab her.

She ran fourteen miles in fifteen days, And never looked behind her.

She got in a wood,

And there she stood,

And the thieves could never find her.

3. From the same.

There was an old man, and he had an old cow,

And how to keep her he didn't know.

He built up a barn to keep his cow warm,

And a little more drink it will do you no harm!

There was an old man, and he had an old cat, And she kep' herself most wonderful fat.

And always was catching the mice in the barn,

And a little more drink will do us no harm.

4. From Mrs. Shaw, an old woman since dead. Pinkney's Green, 1898.

Cicely Parsley lived in a den,

She brewed good ale for gentlemen,

Gentlemen came there twice a day,

Yet Cicely Parsley ran away!

5. From the same.

Little pretty Nancy girl,

She sat upon the green,

Scouring of her candlesticks,

They were not very clean.

Her cupboard, that was musty,

Her table, that was dusty ;

And pretty little Nancy girl, she was not very lusty !

6. From the same.

Green sleeves, yellow lace,

Maids, maids, many a pace,

The hachelors are in a pitiful case.

They kiss away all their money 0 ! 
7. From a MS., dated I740, lent by the late Mrs. Samuel Plumbe, High Street, Maidenhead. Supposed to be Wiltshire.

"I prithee, Molly, whistle, And you shall have a cow."

"I fear I cannot whistle, I cannot whistle now."

"I prithee, Molly, whistle, And you shall have a man."

"I fear I cannot whistle, But I'll whistle as well as I can."

(See variants in Northall's English Folk-Rhymes, p. 295.)

8. From the same.

Fiddle-de-dee, fiddle-de-dee !

The wasp has married the humble bee !

Puss came dancing out of the barn

With a pair of bagpipes under her arm.

One for Johnnie and one for me,

Fiddle-de-dee, fiddle-de-dee !

The bull's in the barn, thrashing the corn,

The cock on the dunghill is blowing his horn.

I never saw such a sight since I was born !

9. From the singing, or rather chaunting, of children in Norfolk.

I had a little nabby colt, (?)

His name was Dapple-grey,

His head that was made of pease-straw,

His tail that was made of hay.

I had a little nabby colt No bigger than my finger,

I bridled him and saddled him,

And sent him in to town.

I sent him to the garden.

To pick a little sage,

He popped into the kitchen

And kissed the pretty maids.

Kate LeE.

II. Heard at Wensleydale, Yorkshire.

Shak' a leg, shak' a leg,

Where will t' gang ?

Gang wi' me mammy,

When days is lang.

When days is lang

And loans is dry, 
Gang wi' me mammy

To milk cushie kye.

And when we come to $t$ ' sty'e

Then we joump o'er ' $t$ l

Margarei Eyre.

III. A riddle, from Morley, near Wakefield.

Peter Flickem had a barn [child],

It had neither leg nor arm,

It had neither back nor belly,

Eh, poor thing ! they called it Nelly.

Answer. An umbrella.

S. O. ADDY.

IV. From Secunderabad, Deccan.

" Konga, konga, ammavari gudilo, poovaisi po, Konga, konga, ammavari gudilo, poovaisi po."

"Crane, crane, put a flower in the goddess's temple."

Thus repeat boys and girls in a sing-song tune on seeing a flight of white cranes in the skies, rubbing at the same time the nails of the four fingers (but not the thumb) of one hand with those of the other, with the hope that white specks, which they compare to a flower, will appear on the nail, which they call a goddess's temple, from its shape. The figure is very apt. . No speck appears there and then, but on seeing a speck which they have not noticed before, they contend that it appeared there and theri.

2. A boy's riddle.

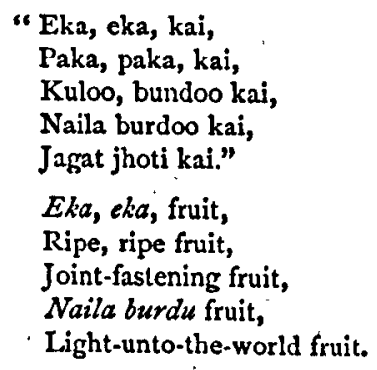

The meaning of the words in italics is difficult to trace; they are not found in a dictionary.

[The answer to the riddle, if we understand Mr. Venkataswami's notes rightly, is ".Man."] 
3. "Chunda mama, Chunda mama, chhakanga rayai !

Golakonda pothamoo,

Gorraini testamu.

Gorrai buddaidu pálu ichhay

Pálu teesookoni komatodiki ichhai ;

Komatodoo cobbaira bellamu ichhai ;

Cobbaira bellamu teesookoni swamilli ichhay;

Swami poovoo ichhay,

Poovoo teesookoni ma akka koppulo pettinanu."

" Uncle moon, uncle moon, come straight !

[We] shall go to Golconda,

[And] bring an ewe.

The ewe gave a bottle of milk;

Taking the milk [we] gave it to [the] Komati ;

The Komati gave cocoanut and jaggery ; ${ }^{2}$

Taking the cocoanut and jaggery, we gave to God;

The God gave [a] flower ;

Taking the flower [I] put it in my sister's braid of hair."

Thus repeats the father or elderly person, pointing out the moon to the crying child, and soothing him to quiet.

4. Bâvâ, bâvâ, bullairu, Bâvani putti tunnairu, Eedi eedi tippairu E'ra gundum poosairu.

" Brother-in-law, brother-in-law, is a bulli root. .

Brother-in-law is caught and kicked,

Paraded from street to street,

And rubbed [with ?] dirt-paste."

Thus repeats the younger sister-in-law, with a view to deride her brother-in-law.

5. Ā pancha roka kookka, E pancha voka kookka, Nadi pancha ma bâvà kookka

Vundaina voka vailla vonto kookka.

"On this side of the piyal" there's a dog,

On that side of the 'piyal there's a dog,

In the centre of the piyal there's my brother-in-law dog,

[Who] was at one time a solitary dog."

I Komati, a shopkeeper, merchant.

2Jaggery, juice of the sugar-cane, unrefined sugar.

'Piyal, a roof on posts, erected over a platform.' 
So says the younger sister-in-law, in a sing-song tone, contrasting the condition of her brother-in-law before he had married her sister; a condition which she regards as that of a dog snarling at everything. Amongst Hindus celibacy is looked down upon. Every Hindu is a married man.

6. Nagi, Nagi, nullairu, Nagini putts tunnairu Cheekati kottulo vaisairu Chuppidi gungi posairoo.

"Nâgi, Nagi is a nulli root. Nâgi is caught and kicked ; [She is] put in a dark room And given conjec ' without salt."

Thus repeats one female playmate of another by way of a taunt. Nagi is the name of a girl. It is not known what is meant by nulli root.

M. N. Venkataswami.

24th August, 1900; 7th February, 1901.

' Conjec, porridge, any, kind of sloppy food. 